\title{
Susceptibilities of Escherichia coli from Gut of Pigs against Animal Feed Additive Colistin under Anaerobic condition
}

\author{
Keiji Ogimoto, Tamio Inamoto and Keijiro Nirasawa \\ Department of Animal Science, \\ Tohoku University. Sendai-shi 980
}

(Received March 2, 1979)

The gut of animals which is the habitat of intestinal bacterial flora is under highly anerobic and redactive conditions, and the oxidation-reduction potential in these has been showed to be $-350 \mathrm{mV}$ to $-50 \mathrm{mV}^{1-2}$. So, the antibacterial activity of the antibiotic in the gut of animals has to be reacted under anaerobic condition. However, procedures of the antibiotic susceptibility testing has been usually examined under the aerobic condition ${ }^{3)}$. It is known a little about the relation of susceptibilities of bacteria against antibiotics under aerobic and anrerobic conditions ${ }^{4}$. However, it is not known about these against colistin as feed additive for livestocks. Colistin is antibiotic agent belonging to the polymyxin group of which chemical structure is cyclic polypeptide, and is known to exert its potent antibiotic efficacy against the gram-negative bacteria, such as Escherichia coli, Salmonella and Bordetella ${ }^{5-7)}$. Colistin is widely used in feed additive for domestic animals in Japan. Present studies were carried out to make clear the susceptibilities of several strains of $E$. coli isolated from gut of pigs against colistin under aerobic and anaerobic conditions.

\section{Materials and Methods}

Strains: One hundred and ninety-four strains of $E$. coli isolated from 126 pigs reared in Tohoku and Kanto areas of Japan were employed for this study. Standard strain for the susceptibility tests was $E$. coli strain NIHJ JC-2 maintained in our laboratory.

Isolation of $E$, coli: One gram of the rectum contents of the pigs was stirred and homogenized. Then, they were diluted gradationally from $10^{-1}$ to $10^{-6}$ with tenfold dilution. Each $0.1 \mathrm{ml}$ of them was spread onto DHL agar (Nissui) plates. The plates were incubated overnight at $37^{\circ} \mathrm{C}$. These screened strains were identified as E. coli according to the biochemical tests by Ewing and Martin ${ }^{8)}$.

プタ由来大腸菌の嫌気下に扮けるコリスチン感受性：扇无敬司・稲元民夫・菲沢圭二郎（東北大学 農学部, 仙台市 980) 
Determination of minimal inhibitory concentration (MIC): The precedures of the Nippon Kagaku Ryoho Gakkai (Japan Society of Chemotherapy) were followed ${ }^{\text {) }}$. Trypticase soy broth (BBL) was used as the medium for growing culture. Each culture was incubated at $37^{\circ} \mathrm{C}$ for 24 houres, and prepared the cell suspension with the density of $10^{8} \mathrm{cell} / \mathrm{ml}$. Determination of the susceptibility tests was done by using the medium of Heart infusion agar (Nissui). Colistin (19400 U/mg. Asahi Chemical Industry, Co., Ltd. Tokyo) was diluted gradationally from $25 \mu \mathrm{g} / \mathrm{ml}$ to $0.10 \mu \mathrm{g} / \mathrm{ml}$ in 10 grades. The MIC was recorded as the lowest concentration of antibiotic that completely inhibited the growth of each strains. The anaerobic culture system used were the steel wool jar ${ }^{10)}$.

\section{Results and Discussion}

Table 1 shows the distribution of the number of tested strains on the susceptibility to colistin under aerobic and anaerobic conditions. Under the anaerobic condition, the suscepiibilities of 105 strains (54\%) were elevated, those in 20 strains (10\%) were reduced, and those in 69 strains $(36 \%)$ were the same under the both cenditions. Accordingly, the susceptibility of various strains of $E$. coli from pigs against colistin was elevated under the anaerobic condition. The susceptibility was, however, strongly related with the strain specificity.

The result of this experiment showed that the susceptibilities of $E$. coli from pigs against colistin were not always same under the aerobic and the anaerobic conditions. ARAI') reported that the susceptibilities of bacteria against various antibiotics were different in accordance with the difference of the test conditions. Aminoglycoside antibiotics, such as streptomycin and kanamycin, are less effective under anaerobic condition than aerobic condition. $\beta$-lactam antibiotics, such as ampicillin are, however, more effective under anaerobic condition than aerobic condition. Chloramphenicol and tetracycline have different effectiveness in accordance with the difference of the strains. Erythromycin, furazolidone and moenomycin have same effectivity both under aerobic

Table 1. Number of $E$. coli on the minimal inhibitory concentration (MIC) to colistin under aerobic and anaerobic conditions.

\begin{tabular}{|c|c|c|c|c|c|c|c|c|c|}
\hline \multirow{2}{*}{\multicolumn{2}{|c|}{$\operatorname{MIC}(\mu \mathrm{g} / \mathrm{m} l)$}} & \multicolumn{8}{|c|}{$\begin{array}{c}\text { MIC of colistin to } E \text {. coli strains under } \\
\text { aerobic condition }(\mu \mathrm{g} / \mathrm{m} l)\end{array}$} \\
\hline & & 12.5 & 6.25 & 3.13 & 1.56 & 0.78 & 0.39 & 0.20 & 0.10 \\
\hline \multirow{8}{*}{ 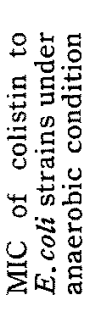 } & 12.5 & 1 & & & & & & & \\
\hline & 6.25 & & & & & & & & \\
\hline & 3.13 & & & & & & & & \\
\hline & 1.56 & & & & & & & & \\
\hline & 0.78 & & & & 1 & 10 & 18 & & \\
\hline & 0.39 & & & & 2 & 48 & 45 & 2 & \\
\hline & 0.20 & & & & & 5 & 49 & 13 & \\
\hline & 0.10 & & & & & & & & \\
\hline
\end{tabular}


and anaerobic conditions. The preparation of culture media and the cultivation techniques employed in the present study were rather moderate anaerobic condition ${ }^{11-12}$. So the different results might be obtained with the media prepared by the pre-reduced methods ${ }^{13)}$ which have been applied for the anaerobic cultivation of Bacteroides, Selenomonas and other intestinal bacteria.

We thank Dr. M. Nakamura of National Veterinary Assay Laboratory, Tokyo, for his helpful criticism and review of this study. We also thank Mr. K. NARITA and Mr. I. Fujimatsu of Food and Fine Chemical division, Asahi Chemical Industry Co., Ltd., Tokyo, for their supply of colistin sulfate.

\section{References}

1) Shibata, A., K. Ogmoto and C. Furusaka, Japan. J. Zootech. Sci., 31: 290-294. 1960.

2) Clarke, R. T. J. and T. Bauchop, in Microbial Ecology of the Gut. 38-41. Academic Press. New York. 1977.

3) Sherris, J.C., in Manual of Clinical Microbiology. 2nd ed. (Lennette, E. H., E. H. Spaulding and J.P. Truant, eds.) 407-409. American Society for Microbiology, Washington, D.C. 1974.

4) Arai, T., Keio. J. Med., 26: 31-42. 1977.

5) Schwartz, B.S., M. R. Warren, F. A. Barkely and L. Landis, in Antibiotics Annual 19591960. (Welch, H. and F. Marti-Ibanez, eds.) 41-60. Antibiotica, Inc., New York. 1960.

6) Wright, W.W. and H. WeLCH, in Antibiotics Annual 1959-1960. (Welch, H. and F. MarTIIbanz. eds) 61-74. Antibiotica. Inc., New York. 1960.

7) Fingold, S. M., D. J. Posmick, L.G. Miller and W. L. Hewitt, Ernährungsforschung, 10: 316-341. 1965.

8) Ewing, W.H. and W. J. Martin, in Manual of Clinical Microbiology. 2nd ed. (Lennette, E. H., E. H. Spauling and J.P. Truant, eds.) 189-221. American Soiety for Microbiology, Washington, D.C. 1974.

9) Ithiyama, S., Y. Ueda, S. Kuwahara, N. Kosakal, G. Furuya, M. Konno and Y. Fujt, Chmotherapy, 16: 98-99. 1968.

10) Azuma, R., K. Ogimoto, and T. Suto, Japan. J. Bacteriol,, 17: 802-805. 1962.

11) Walden, W.C. and D. J. Hentges, Applied. Microbiol., 30: 781-785. 1975.

12) Drassar, B. S. and M. J. Hill, in Human Intestinal Flora. 3-8. Aacdemic Press. New York. 1974.

13) Holdeman, L. V. and W. E. C. Moore, Amer. J. Clin. Nutr., 25: 1314-1317. 1972. 